Monyane, T.G., Emuze, F.A., and Crafford, G. (2018). "Identification of lean opportunities in a South African public sector projects cost management framework." In: Proc. $26^{\text {th }}$ Annual Conference of the International. Group for Lean Construction (IGLC), González, V.A. (ed.), Chennai, India, pp. 1185-1194. DOI: doi.org/10.24928/2018/0207. Available at: www.iglc.net

\title{
IDENTIFICATION OF LEAN OPPORTUNITIES IN A SOUTH AFRICAN PUBLIC-SECTOR PROJECTS COST MANAGEMENT FRAMEWORK
}

\author{
Thabiso G. Monyane ${ }^{1}$, Fidelis A. Emuze ${ }^{2}$, and Gerrit Crafford ${ }^{3}$
}

\begin{abstract}
The prevalence of cost overruns in public sector construction projects in South Africa has been observed. This has been attributed to ineffectual approaches to cost management within these projects. The prior study by the authors has made sense of these observations an understanding of existing cost management approaches. Accordingly, this study seeks to identify Lean opportunities from existing cost management practices. Such opportunities will enable identification of effective cost management during project delivery. Adopting a qualitative case study research design, the study relies on data obtained from a purposively selected list of interviewees from a cadre of cases, i.e., recently completed public sector construction projects in South Africa. These interviews will be juxtaposed with evidence from project-related documents. Based on the data, the study will provide a vignette of lean-led cost management frameworks applied to these projects. Encompassing various stages of the project delivery lifecycle, this vignette will enable an identification lean lead cost management on these projects. Subsequently, the vignette will be validated by interviewees. The expectation is that findings from this study will provide a brief picture of cost management frameworks and enable the introduction of probable lean-based solutions to reverse this unbecoming trend.
\end{abstract}

\section{KEYWORDS}

Construction Projects, Cost Management, Public Sector, Vignette, South Africa

\section{INTRODUCTION}

The public-sector client emphasized infrastructure investment as a driver of the economy, but the consequence of constraints realized on project delivery did not provide expected

1 Doctoral candidate, Built Environment Dept., CUT, FS - Central Univ. of Technology, Free State, RSA, +2751 507-3537, tmonyane@ cut.ac.za

2 Associate Professor, Built Environment Dept., CUT, FS - Central Univ. of Technology, Free State, RSA, +2751 507-3089, femuze@ cut.ac.za

3 Associate Professor, NMU - Nelson Mandela University, Port Elizabeth, South Africa, +2741 504 2153, gerrit.crafford@nmu.ac.za 
outcomes. Efforts of Watermeyeret al., (2013) purported that infrastructure spending will not necessarily lead to economic growth. However, Watermeyeret al.,.(2013) Supposed that improved infrastructure that is delivered and maintained in a way that minimizes waste of materials, time and effort permissible to generate the maximum possible amount of value, is most likely to contribute to economic growth. To create value, Orihuela, Orihuela, and Pacheco (2015) state that the service rendered by professionals must be improved and the cost of the services to be reduced or enhanced to the satisfaction of project participants. According to Forbes and Ahmed (2011), productivity in construction has always been lower than that of other industries. Again, Forbes and Ahmed (2011) emphasize that much of the improvement in the construction industry is attributed to research and development work in the manufacturing sector relating to machinery. Consequently, the construction industry research and development remained low as a result. There are attempts by the South African public sector to improve the project delivery methods in the country. Such attempts can be attributable to the separation of the supply chain of general goods and infrastructure procurement implemented from July of 2016.. However, there still remains a challenge on how early contractor involvement is to be adopted to the current procurement system. Thus far there hasn't been any publicsector project that has used the strategy as due to the challenge on how to introduce the contractor early in the current procurement system.

However, pre-contract cost management in a South African context involves an advisory service provided by consultants to a client on the price to design and construct a project. This is very much an isolated task driven solely by the cost manager on the project with little regard to collaborative costing by all project participants. The practice of neglecting collaborative approach to costing has arguably been the major cause of cost overruns experienced on construction projects (Namadi, Pasquire and Manu 2017).

Prior studies by the authors of this study reported on the status quo of projects cost management; study identified the challenges hindering effective project cost management in the delivery of projects in South Africa. Four case study projects were evaluated and validated by interviews with project participants to strengthen the comprehension of the status quo of cost management approaches used in the South African construction industry. The objective of this study is to provide a vignetteof lean-led cost management framework applied to these projects. Various stages and activities by the project planning teams are revealed from inception until project construction completion. The vignette displays lean opportunities to add value by eliminating waste, reduction of lead times, cost optimization.

\section{LITERATURE REVIEW}

\section{PROJECT COST ESTIMATING}

The process of estimating costs in South Africa considers the numerous life cycle phases until the final design is completed and the Bill of Quantities (BoQ) is produced (Clough \& Sears, 1999: 19) cited by(Seeletse and Ladzani 2012). For cost management to be successful, cost estimating is one of the primary tools to develop such estimates (design, bid or control) as may be required (Oyedele 2015). From the onset as soon as the project 
owner provides a project definition task to the professional team, instantaneously every activity undertaken from thereon affects the cost of the project. Cost is of vital importance to the planning, designing and constructing of a project (Grant and Owen 2009). According to PMI (2015), management from a project perspective involves the application of knowledge, skills, tools, and techniques to project activities to meet the project requirements. Estimates are prevalently used for the initial estimate and feasibility of the project. Also, the estimates are produced from preliminary sketches undertaken by the architect from the project definition stage given by the project owner. Assessment of conceptual estimates An et al., (2007) identified the following factors to affect estimate accuracy: changed drawings, changed specifications, and changed project scope and concluded that it is impossible to predict all expected changes correctly. In South Africa, the estimate is being conducted by the quantity surveyor developed from the preliminary drawings supplied by the architect. The cost management process follows the traditional method of design-bid-build of which in South Africa is referred to as design by the employer. According to Odideran and Windapo (2015), there is no doubt that the driving force of project success is emanating from effective project cost management.

\section{PROJECT COST MANAGEMENT}

Project cost management involves various elements that, once followed diligently, make the cost management process easy and straightforward. Project cost management entails resource planning, cost estimating, cost budgeting, and cost auditing and or cost control (Knipe, van Der Walt, van Niekerk, Burger and Nell 2011). Bestowing what Kirkham (2007) purports, cost planning as a process is complicated to outline succinctly as it entails various procedures and techniques used concurrently by the quantity surveyor or building economist. The management of costs in a project is a common thread that runs through the complete life cycle of the project (Steyn, Caruthers, du Plessis, Kruger, Kuschke, Sparrius, Eck, Visser 2013). According to Keong (2010), cost management of a project is one of the fundamental processes to bring about the success of a project to be delivered within budget and control expenses incurred in the project. As Kirkham (2007) reported traditional cost planning will usually follow a conventional outline design, and then detailed design process. The management of costs begins with the financial viability study, progresses through all the costs that are required to purchase all the resources needed by the project, through to using cost control to ensure that all work that is done is adequately completed (Steyn et al. 2013).

Figure 1 below is an observation made by the authors in a previous study, were a vignette has been produced for the status quo of cost management process for the delivery of the public project is South Africa. The South African Public Works procurement system uses the traditional design-bid-build and has not established any other method of procurement to deliver projects. The public works execute projects with the mandate from other national client departments. As such the public works projects are only allowed to use competitive bidding system from contractors according to the Public Finance Management Act. This hinders an opportunity to introduce early contractor involvement and appoints based on lowest price. And then contractors are hesitant to revise prices lower than appointed costs, due to fear of losing out on profit margins. 


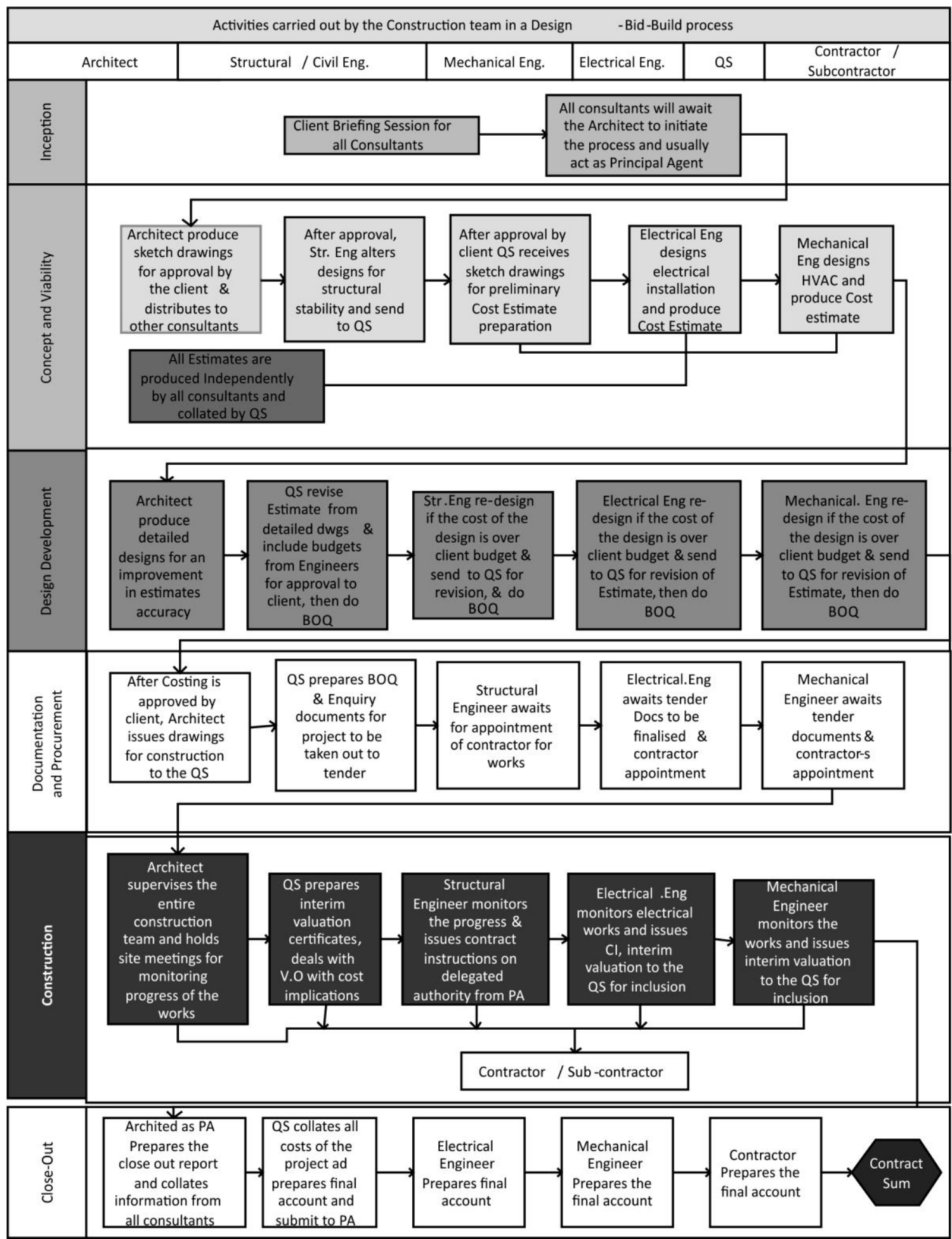

Figure 1: Activities by project participants on public sector projects (Monyane et al. 2017) 


\section{RESEARCH METHOD}

To achieve the purpose of this research, the study adopted the qualitative research design, from a coterie of recently completed cases of the public sector in South Africa. Usage of a case study is prevalent in situations where researchers intend to understand a contemporary phenomenon within a contextual condition when they possess low control over proceedings. A descriptive case study was chosen, and Yin (2014) imply such type of case study is employed when context-specific insight is sought. Also, a case study is known for its legendary reputation for promoting a painstaking investigation of a phenomenon within its contextual context. To sustain a replication logic across cases, multiple cases were encouraged to be employed in this study including numerous sources of evidence to advocate construct validity (Yin 2014). Means of document analysis analysed the textual data. The document analysis data were supplemented with semistructured interview data collected from project actors in the selected cases. Interviews were recorded and transcribed using thematic analysis. To rule out bias sample comprised of participants form the cases chosen for the study. 15 Semi-structured interviews which lasted from 30 to 40 minutes were employed to gather data for the avoidance of same questions but that of similar ones if structured interviews were used (Denscombe 2010). From the cohort of interviewees professionals such Architects, Project Managers, Quantity Surveyors, Structural, Mechanical, Electrical Engineers were drawn from the sample respectively. Pre-set themes which were aligned with the research objectives of the study were developed and utilized for this study. Pre-set themes evolved from the coded data. Interviewees were requested to discuss their processes of designing and cost management in the pre-contract stage through to appointment of the contractor. Secondly, the interviewees were asked to validate lean opportunities identified from the process of design and cost management of public projects, specifically the project cases selected for this study.

\section{RESULTS AND DISCUSSIONS}

Table 1 below is two cases of projects selected for document analysis of the cost performance of projects in South Africa. The two projects performed poorly regarding both cost and time performance regarding the project management success parameters. The projects used the traditional system of executing projects for public sector clients. Table 2 is the other two cases of projects selected for document analysis, which performed well concerning project management success parameters. Two schools' projects employed the Design-build procurement system while the two hospital projects employed the traditional-bid-build, procurement system to execute the projects. Response by interviewees of the professional team regarding the reasons for such deviations from the poorly performed projects based on cost and time, was that every project is unique, and changes will always occur, and it is part of the construction process. The role of the project manager on such projects was somewhat clashing with that of the architect who is project managing the project due to being appointed Principal-Agent (PA) according to the Joint Building Contracts Committee 6.1 edition on the two schools. The contract does 
not necessarily stipulate who should be the PA, but since the architect gets appointed first, the position automatically favours the latter and other appointments are made after.

Table 1: Project 1 and Project 2

\begin{tabular}{|c|c|c|c|}
\hline $\begin{array}{l}\text { PROJECT } \\
\text { INFORMATION } \\
\end{array}$ & Project 1 & $\begin{array}{l}\text { PROJECT } \\
\text { INFORMATION }\end{array}$ & Project 2 \\
\hline Department & Department of Health & Department & $\begin{array}{l}\text { Department of } \\
\text { Education }\end{array}$ \\
\hline Project Name & $\begin{array}{l}\text { Extension to Boitumelo } \\
\text { Hospital }\end{array}$ & Project Name & $\begin{array}{l}\text { New Primary } \\
\text { School }\end{array}$ \\
\hline Town & Kroonstad & Town & Bothaville \\
\hline $\begin{array}{l}\text { Date of site } \\
\text { handover }\end{array}$ & 28 July 2011 & Date of site handover & 02 October 2013 \\
\hline Actual start date & 21 November 2011 & Actual start date & 02 October 2013 \\
\hline Completion date & November 2014 & Completion date & 29 May 2015 \\
\hline $\begin{array}{l}\text { Actual completion } \\
\text { date }\end{array}$ & April 2015 & Actual completion date & 29 May 2015 \\
\hline Contract Amount & R138 263009.29 & Contract Amount & R28 152536.86 \\
\hline Final Amount & R170 339718.37 & Final Amount & R32 758734.81 \\
\hline Overrun amount & R32 076709.05 & Overrun amount & R4 606197.95 \\
\hline
\end{tabular}

Table 2: Project 3 and Project 4

\begin{tabular}{|c|c|c|c|}
\hline $\begin{array}{l}\text { PROJECT } \\
\text { INFORMATION }\end{array}$ & Project 3 & $\begin{array}{l}\text { PROJECT } \\
\text { INFORMATION }\end{array}$ & Project 4 \\
\hline Department & Department of Health & Department & $\begin{array}{l}\text { Department of } \\
\text { Education }\end{array}$ \\
\hline Project Name & New Mantsopa Hospital & Project Name & New Special School \\
\hline Town & Ladybrand & Town & Kroonstad \\
\hline $\begin{array}{l}\text { Date of site } \\
\text { handover }\end{array}$ & 12 August 2010 & Date of site handover & 02 March 2016 \\
\hline Actual start date & 12 August 2010 & Actual start date & 02 October 2017 \\
\hline Completion date & 12 January 2013 & Completion date & 02 October 2017 \\
\hline $\begin{array}{l}\text { Actual completion } \\
\text { date }\end{array}$ & 12 January 2013 & Actual completion date & 02 October 2017 \\
\hline Contract Amount & R264 662777.29 & Contract Amount & R39 400000.00 \\
\hline Final Amount & R264 662777.29 & Final Amount & R38 977652.13 \\
\hline Overrun amount & $\mathrm{R} 0.00$ & Overrun amount & - R422 347.87 \\
\hline
\end{tabular}


The status quo of South African construction remains a challenge to get projects to enhance their performance. Figure 1 above from previous study represents the process of cost management of public projects in South Africa. This figure has been developed based on the findings of the semi-structured interviews by supply chain officials and the project participants. Projects performed poorly in terms of cost and time from the cohort of case studies above. The two projects that performed poorly, resulted from revision of drawings by the architect on instructions from the client. This brought about variations with cost implications to the projects. Other reasons are request for information by the contractor to the client which response was very slow therefore halting certain tasks by the contractor due to lack of information forthcoming. There is an initiative by the regional public works to employ early contractor involvement to be part of the design and cost management process, but the challenge is on how it should be implemented. The question was around whether the contractor be a consultant to the project or appoint the contractor early and based on which criteria as the public sector has a challenge of using competitive bidding as per the Public Finance Management Act. The contractor's aim is to maximise profits and if appointed based on price, then contractor might not agree for project cost to be revised lower which brings a challenge of revising the procurement system of traditional design-bid-build system. The challenge brought by the traditional design-bid-build is that it does not allow multi party agreement and to use incentives to promote collaboration between project participants.

The objective of the study is to identify opportunities for lean construction from the above vignette in figure 1 of the outcome of extant cost management. Within the South African context, little is known about the application of Lean thinking strategies to better the overall success of the project. Lean introduction for the past two decades has no doubt posed a challenge for the traditional project management practice (Alarcon, Mesa, and Howell 2013). The identified lean tools from lean-led case studies were suggested to the Interviewees for them to comment on whether they will assist to overcome the poor performance recorded based on time and cost on the public-sector projects in South Africa, see figure 3 for such tools. Figure 2 below is the identified lean opportunities to convince the project participants interviewed based on the case studies of South African projects in this study.

As mentioned before lean is a new philosophy in South African construction, and most practitioners believe the status quo still works if more effort is emphasized on public sector procedures. Whatever waste arising from different projects, to most of the interviewees it is a norm that projects will perform badly with some, and projects will perform better with others. Applying innovation to reduce waste arising out of the cost management process is not the only thing that will root out the problems. The arguments put forward by the project participants required an evidence-based approach to obtain their buy-in of the lean opportunities deemed appropriate for the current status quo of project cost performance. 


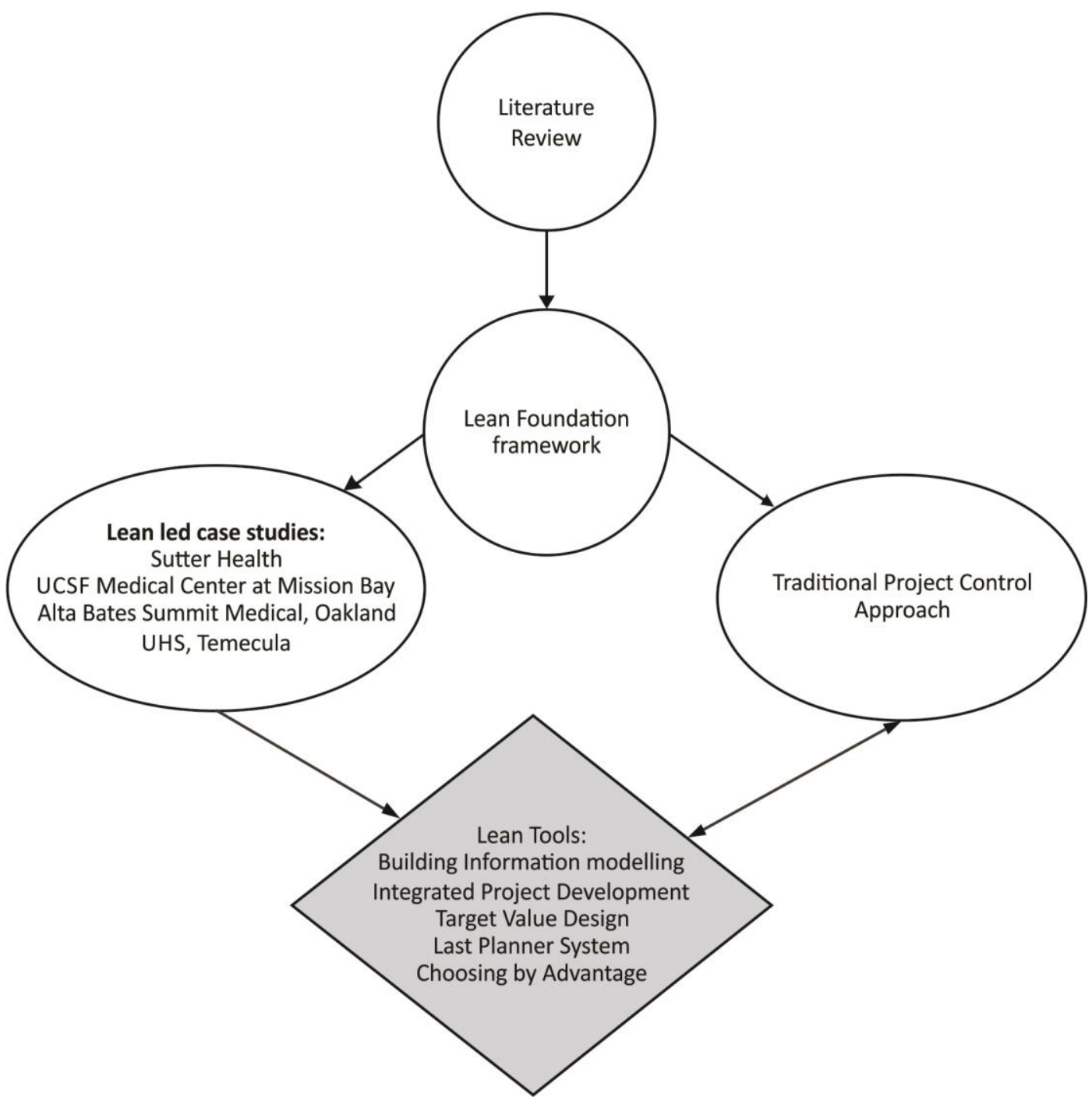

Figure 2: Lean Opportunities Identified (Author)

The authors chose the lean foundation framework, coupled with literature to support the identified opportunities of lean suggested tools. Secondly, the lean led case studies were compared with the traditional project management practice project executed in South Africa were waste dominated the entire lifecycle of the projects. Lean case studies were shown to the respondents, and a few of the well-known projects that performed poorly were drawn from the literature as well. Various lean tools were then suggested and explained to the respondents on how they will be applied and their benefits to the improvement of project performance and how they were used on lean-led case studies already demonstrated to the respondents earlier. BIM, Lean IPD, TVD, CBA, Last Planner System to be implemented on the constructions stage to improve the duration of projects. The respondents agreed that such lean tools are convincing to improve the current status quo and although some of them will require the political support as they affect policy changes notably the appointment of contractors, to bring them early to get 
involved. But BIM was supported entirely by respondents and agreed that it has a high possibility of improving the flow of design and construction at the same time. BIM was supported based on the fact that it provides the opportunity to fine tune the design and evaluate any clashes before construction starts. Designs can be viewed in a 3D to eliminate any errors early, rather than a 2D drawing which does not illustrate the entire design. TVD was preferred by the respondents highly, however, the disadvantage was that they preferred it on mega projects which requires time before the design can be finalised. It was however, ruled out on small projects and when time is of the essence to implement projects. Other tools were suggested, but if they were time-consuming, the respondents ruled them out on the basis that they are usually not provided such a long time to implement projects. Last planner system was supported fully by the respondents and with training respondents believe that it has a future on construction projects in South Africa. IPD will still take some time before it can be fully implemented in South Africa as respondents alluded, that IPDish at the moment poses a challenge as there is no consensus on how to

\section{CONCLUSIONS}

The study intended to bring across results of the status quo of public sector projects and sought the cost management process of executing those projects through the interviews and identify lean opportunities that may be implemented to reverse the ills experienced on public projects. The lean opportunities identified, have the highest chance of improving the cost management process and the projects in its entirety as some were deemed appropriate but due to limited times sometimes offered to implement projects respondents ruled them out on projects were time was limited to implement but appropriate for mega projects. The authors believe that the most significant challenge of achieving lean in South Africa will mainly be culture change before lean construction can flourish as a philosophy to bring about change.

\section{ACKNOWLEDGMENTS}

The author(s) wishes to acknowledge the National Research Foundation - Thuthuka Funding Instrument - 93968 that has made this study possible.

\section{REFERENCES}

Alarcón, L.F., Mesa, H. \& Howell, G. (2013). 'Characterization of Lean Project Delivery' In:, Formoso, C.T. \& Tzortzopoulos, P., $21^{\text {st }}$ Annual Conference of the International Group for Lean Construction. Fortaleza, Brazil, 31-2 Aug 2013. pp 247-255.

An, S.-H., Park, U. Y., Kang, K.-I., Cho, M.-Y. and Cho, H.-H. (2007) Application of support vector machines in assessing conceptual cost estimates. Journal of Computing in Civil Engineering, 21(4), 259-264.

Denscombe, M. (2010). The good research guide: for small-scale social research, McGraw Hill. 
Forbes, L.H. \& Ahmed, S.M. (2011). Modern Construction: Lean Project Delivery and Integrated Practices. London: CRC Press.

Grant, B, Owen, C,C,C, (2009). Enhancing the role of the Construction Cost Consultant. Cost Engineering Vol. 51(9), 11-15. CERTIFICATION PAPER.

Keong, W, (2010). A study into effectiveness of project cost control in overcoming costs overrun for turnkey project in Malaysia. MSC Dissertation, Heriott-Watt University.

Knipe, A, Van der Waldt, G, Van Niekerk, D, Burger, D and Nell, K (2011). Project Management for Success. Sandown: Heinemann.

Namadi, S., Pasquire, C., and Manu, E. (2017). "Discrete Costing Versus Collaborative Costing." In: LC3 2017 Volume II - Proceedings of the 25th Annual Conference of the International Group for Lean Construction (IGLC), Walsh, K., Sacks, R., Brilakis, I. (eds.), Heraklion, Greece, pp. 3-10. DOI: https://doi.org/10.24928/2017/0341

Odediran, S. J., and Windapo, A. O. (2014). Systematic review of factors influencing the cost performance of building projects. In advancing construction industry development through innovative research and new thinking proceedings 8th construction industrydevelopment board $(C I D B)$ post graduate conference University of Witwatersrand South Africa February 10-11 2014. University of Witwatersrand Johannesburg (pp. 501-520).

Orihuela, P, Orihuela, J, Pacheco, S, (2015). Implementation of Target Value Design (TVD) in building projects. Creative Construction Conference, 21 - 24 June, Krakow, Poland.

Project Management Institute, Project management Body of knowledge 2015.

Seeletse, S, Ladzani, W, (2012). Project Cost Estimation techniques used by most emerging building contractors of South Africa. Acta Structilia 19 (1), 106 - 125.

Steyn, H, Basson, G, Kruger, D, Pienaar, J, Prozesky-Kuschke, B, van Eck, S, Visser, K, (2011). FPM Publishing.

www. National Treasury. gov. za [accessed 20 February 2018]

Watermeyer, R, Wall, K, Pirie, G, (2013). How Infrastructure delivery can find its way again. IMIESA Infrastructure Delivery Congress, Expert Analysis

Yin, R, (2014). Case study Research: Design and Methods, 5th Edition, SAGE, ISBN 978-1-4522-4256-9. 